Nig. J. Biotech. Vol. 37(2): 157-164 (Dec. 2020)

ISSN: 01891731

Available online at

http://www.ajol.info/index.php/njb/index

and www.biotechsocietynigeria.org

DOI: https://dx.doi.org/10.4314/njb.v37i2.16

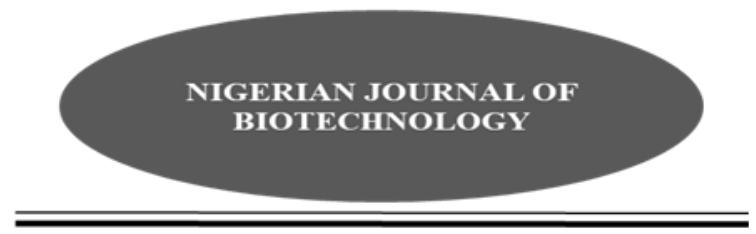

\title{
Effects of processing on amino acids composition of Leucaena leucocephala (Lam De Wit) leaf meal
}

\author{
AGBO, A. N. \\ National Open University of Nigeria, Faculty of Agricultural Sciences Kaduna.
}

\begin{abstract}
The high cost of animal protein sources has made it necessary to evaluate the use of alternative plant protein sources especially unconventional plant proteins. Leucaena leucocephala (white lead tree) is a leguminous plant, the leaves of which have the potential of being used as a plant protein source. Leucaena leaf has been analysed to have a crude protein value of 15.2$34.3 \%$. The plant leaves were collected from the forage section of the College of Agriculture and Animal Sciences (CAAS) Mando, Kaduna. The first group of the leaves was divided into three and sun-dried for 24 hours, 48 hours and 72 hours respectively. The second group was further divided into three subgroups which were soaked in water for 24 hours, 48 hours and 72 hours then sun-dried. The two groups of the leaves were ground into leaf powder. The effects of sun-drying and soaking on amino acid composition of $L$. leucocephala leaves was investigated. The amino acid analysis was done by ion-exchange chromatography (IEC) using the Technicon Sequential Multisample Amino Acid Analyser (TSM) Technicon Instruments Corporation, New York. The essential amino acids detected in L. leucocephala leaf were arginine, histidine, isoleucine, leucine, lysine, methionine, phenylalanine, threonine and valine. Alanine, cysteine, tyrosine, aspartic acid, glutamic acid, glycine, serine and proline were the non-essential amino acids detected. Sun-drying and soaking led to significant ( $P \leq 0.05)$ losses in the concentration of all the amino acids in the leaf samples (Sundried for 24 hours - SD, Sundried for 48 hours - SD for 72 hours - $S D_{3}$, soaked in water for 24 hours - SW soaked in water for $\mathbf{7 2}$ hours - $\mathrm{SW}_{3}$ ) when compared with the raw leaf samples (SU). Soaking caused higher reduction in the amino acid levels when compared to sun-drying in the test leaf meals which was significant at $P \leq 0.05$. The amino acid scores revealed that lysine and methionine were the limiting amino acids in L. leucocephala leaves relative to WHO/FAO/UNU standard for preschool aged children. Therefore, processed $L$. leucocephala leaves should be supplemented with other feed ingredients rich in these amino acids for animal feed production.
\end{abstract}

Keywords: Leucaena leucocephala leaf, sun-drying, soaking, amino acid composition.

Corresponding author: ronkeagbo@gmail.com Introduction

The high cost of traditional protein-rich ingredients has compelled animal nutritionists to explore the use of other unconventional proteinrich feed ingredients. The research into some of these feed ingredients stems from their rich nutrients such as essential amino acids, vitamins and minerals (Aye, 2013). However, the presence of anti-nutritional factors and imbalance of amino acids in plants has limited the usage of these feed ingredients especially plant proteins (Francis et al., 2001). It is well established that amino acids, as nutrients, are building blocks of protein which play an essential role in determining the quality 
and bioavailability of a proteinous ingredients (Robinson and Menghe, 2007). Amino acids can be grouped into essential and non-essential amino acids. The level and proportion of essential amino acids in proteins is important because there must be proper balance for the amino acids to be useful (Robinson and Menghe, 2007).

Plant proteins require some form of processing to reduce antinutritional factors and make their nutrients available (Onimisi et al., 2017). Some of the processing methods employed are cooking, roasting, soaking, boiling, autoclaving, radiation, sun-drying, dehulling, germination, toasting, extrusion, blanching, malting and fermentation (Francis et al., 2001). Simple processing methods such as soaking and sun-drying can be easily used by farmers. The effects of some of these processing methods on amino acid composition has been reported (Chinyere and Obasi, 2011; Augustine et al. 2018).

Leucaena leucocephala (white lead) tree is a fast growing evergreen multipurpose legume which is native to Mexico but has found its way to many tropical and sub-tropical countries (Heuze and Tranc, 2014). L. leucocephala belongs to the family Fabaceae, sub-family Mimosoidae and genus Leucaena ; the tree has bipinnate leaves which are $15-20 \mathrm{~cm}$ long, lanceolate leaflets, flat brown pods containing small seeds and white flowers (Heuze and Tranc, 2014). L. leucocephala trees have been used as wind breakers, ruminants feed, and for agroforestation, nitrogen fixation, paper and timber production (Hetrampf and Piedad-pascual, 2003). The leaves have crude protein values of $15.2-34.3 \%$ dry matter (Foroughbakhch et al., 2007; Monoj and Bandyopadhay, 2007; Ayssiwede et al., 2011, Adedeji et al., 2013). L. leucocephala leaf also contains vitamin A, Vitamin B, carotene and the 10 essential amino acids (Hetramphf and PieddaPascual, 2003; Monoj and Bandyopadhyay, 2007). The objective of this study is to evaluate the effect of sun-drying and soaking on the amino acid composition of Leucaena leaf meal for use in fish nutrition.

\section{Materials and methods}

\section{Collection of $L$. leucocephala leaves}

L. leucocephala leaves were collected from trees planted at the forage section of the College of
Agriculture and Animal Sciences (CAAS) Mando, Kaduna, Nigeria. The leaves were identified at the Department of Pasture and Range Management, College of Agriculture and Animal Sciences (CAAS) Mando, Kaduna after which the leaves were separated from the long leaf stalk and some unwanted materials removed.

\section{Processing of $L$. leucocephala leaves}

Soaking: approximately $500 \mathrm{~g}$ of $\mathrm{L}$. leucocephala leaves was soaked in water at room temperature $\left(30^{\circ} \mathrm{C}\right)$. Ten litres of water was measured into 3 different rubber bowls after which $500 \mathrm{~g}$ of the leaf sample was soaked in one bowl for 24 hours $\left(\mathrm{SW}_{1}\right)$, another $500 \mathrm{~g}$ in the second bowl for 48 hours (SW2) and the third bowl for 72 hours $\left(\mathrm{SW}_{3}\right)$. The leaves were removed from the water and allowed to dry homogeneously in the sun until they became crispy (Amisah et al., 2009).

Sun-drying: about $500 \mathrm{~g}$ of the leaf samples was spread on a concrete slab outside and the first portion was sundried for 24 hours $\left(S_{1}\right)$, the second portion for 48 hours $\left(\mathrm{SD}_{2}\right)$ while the third portion was for 72 hours $\left(\mathrm{SD}_{3}\right)$ as described by Ayssiwede et al. (2011).

All the dried leaf samples were ground into fine powder and separately packed in labelled polythene bags. Representative samples of the leaf meal were taken to the laboratory for amino acid analysis. All analyses were done in triplicates.

\section{Determination of Amino Acid Profile}

The amino acids composition of the leaf sample was analysed as described by Benitez (1989). Two grams of each sample was defatted with chloroform-methanol (2:1) using soxhlet extraction apparatus as described by AOAC (1990). The extraction was carried out for 15 hours. A defatted sample of 30 to $35 \mathrm{mg}$ was weighed into a glass ampoule. Approximately $7 \mathrm{ml}$ of $6 \mathrm{~N} \mathrm{HCl}$ was added and oxygen was expelled by passing nitrogen into the ampoule (this is to avoid possible oxidation of some amino acids, such as methionine and cysteine, during hydrolysis ). A bunsen burner flame was used to seal the glass ampoule, after which it was put in an oven preset at $105^{\circ} \mathrm{C}$ for 22 hours. The ampoule was allowed to cool , then the tip was opened and the content was filtered to remove humins. The filtrate was then evaporated to 
dryness at $40^{\circ} \mathrm{C}$ under vacuum in a rotary evaporator. Five (5) $\mathrm{ml}$ of acetate buffer ( $\mathrm{pH} 2.0)$ was used to dissolve the residue, then stored frozen in a plastic specimen bottle .

\section{Loading of the hydrolysate into TSM analyzer}

The amount loaded was between 5 to 10 microlitres. This was dispensed into the cartridge of the analyzer. The TSM analyzer is designed to separate and analyze free acidic, neutral and basic amino acids of the hydrolysate. Method of Calculating Amino Acid Values from the Chromatogram Peaks

The net height of each peak produced by the chart recorder of TSM (each representing an amino acid) was measured. The half-height of the peak on the chart was found and the width of the peak on the half height was accurately measured and recorded. Approximately, the area of each peak was then obtained by multiplying the height with the width at half-height.

The norcleucine equivalent (NE) for each amino acid in the standard mixture was calculated using the formula:

$$
\mathrm{NE}=\frac{\text { Area of Norcleucine Peak }}{\text { Area of each amino acid }}
$$

A constant $\mathrm{S}$ was calculated for each amino acid in the standard mixture using the equation

$u M A A_{s t d}$

$$
S_{\text {std }}=N E_{\text {std }} \times \text { Molecular weight } \times
$$

Finally, the amount of each amino acid present in the sample was calculated in $\mathrm{g} / 16 \mathrm{gN}$ or $\mathrm{g} / 100 \mathrm{~g}$ protein using the following formular:

$$
\begin{gathered}
\text { Concentration }(C)(g / 100 g \text { protein })=N H \times \\
W @ \frac{N H}{2 \times S_{s t d} \times C}
\end{gathered}
$$

Where $\mathrm{C}=\frac{\text { Dilution } \times 16+N H \times W(\text { nlcu })}{\text { Sample } W t(g) \times N \% \times 10 \times \text { vol.loaded }}$

$$
\begin{aligned}
& \mathrm{NH}=\text { Net height } \\
& \text { W }=\text { Width at half height } \\
& \text { nlcu }=\text { Norleucine }
\end{aligned}
$$

Amino acid score

The following formula by WHO/FAO/UNU, (2007) was used to calculate the amino acid score.

Amino acid score

$=\frac{m g \text { of amino acid per } g N \text { in test protein }}{m g \text { of amino acid per } g N \text { in reference protein }}$

\section{Estimation of leaf Samples Protein Quality}

The reference value for good quality protein as described by WHO/FAO/UNU (2007) for children of preschool age was adopted. To estimate the quality of dietary protein in the leaf samples the following parameters were calculated: Total Essential Amino Acid (TEAA), Total Non-Essential Amino Acid (TNEAA) and Total Sulphur Amino Acid (TSAA), as described by Dalibard et al. (2014).

\section{Statistical Analysis:}

The experiment was carried out using a completely randomized design. The data collected was subjected to one-way analysis of variance (ANOVA) and Duncan's multiple range test (DMRT).

\section{Results}

Table 1 shows the amino acid composition of raw, sun-dried and soaked L. leucocephala leaf meals. Lysine, histidine, arginine, valine, methionine, isoleucine, leucine, threonine and phenylalanine were the essential amino acids identified. While the non-essential amino acids were aspartic acid, serine, glutamic acid, proline, glycine, alanine, cysteine and tyrosine. Leucine was the most predominant essential amino acid which ranged from 7.48-9.72 ( $\mathrm{g} / 100 \mathrm{~g}$ protein) while methionine was least abundant with a range of $1.35-1.77(\mathrm{~g} / 100 \mathrm{~g}$ protein). 
Agbo./ Nig. J. Biotech. Vol. 37 Num. 2: 157-164 (Dec 2020)

Table 1: Amino acid composition of raw, sun-dried and soaked L. leucocephala leaf meal

\begin{tabular}{|c|c|c|c|c|c|c|c|c|}
\hline $\begin{array}{l}\text { Amino acid } \\
(\mathrm{g} / 100 \mathrm{~g} \\
\text { protein })\end{array}$ & SU & SD1 & SD2 & $\begin{array}{l}\text { Treatment } \\
\text { s } \\
\text { SD3 }\end{array}$ & SW1 & SW2 & SW3 & $\begin{array}{l}\text { WHO } \\
\text { /FAO } \\
\text { /UNU } \\
\text { Ref } \\
\text { value } \\
1\end{array}$ \\
\hline \multicolumn{9}{|l|}{$\begin{array}{l}\text { Essential } \\
\text { amino acid }\end{array}$} \\
\hline Lysine & $\begin{array}{l}6.05 \pm 0.01 \\
a\end{array}$ & $5.50 \pm 0.5^{b}$ & $\begin{array}{l}5.62 \pm 0.01 \\
b\end{array}$ & $\begin{array}{l}5.73 \pm 0.01 \\
b\end{array}$ & $\begin{array}{l}4.86 \pm 0.01 \\
d\end{array}$ & $\begin{array}{l}4.97 \pm 0.0 \\
1^{\text {cd }}\end{array}$ & $\begin{array}{l}5.79 \pm 0.01 \\
c\end{array}$ & 5.70 \\
\hline Histidine & $\begin{array}{l}2.97 \pm 0.02 \\
a\end{array}$ & $2.74 \pm 0.1^{b}$ & $\begin{array}{l}2.37 \pm 0.03 \\
\mathrm{e}\end{array}$ & $\begin{array}{l}2.59 \pm 0.01 \\
c\end{array}$ & $\begin{array}{l}2.21 \pm 0.01 \\
\mathrm{~g}\end{array}$ & $\begin{array}{l}2.27 \pm 0.0 \\
1^{\mathrm{fg}}\end{array}$ & $\underset{\text { ef }}{2.32 \pm 0.02}$ & 2.00 \\
\hline Arginine & $\begin{array}{l}6.37 \pm 0.02 \\
a\end{array}$ & $6.11 \pm 0.1^{b}$ & $\begin{array}{l}5.87 \pm 0.01 \\
c\end{array}$ & $\begin{array}{l}5.87 \pm 0.01 \\
c\end{array}$ & $\begin{array}{l}5.18 \pm 0.01 \\
f\end{array}$ & $\begin{array}{l}5.35 \pm 0.0 \\
1^{\mathrm{e}}\end{array}$ & $\begin{array}{l}5.70 \pm 0.02 \\
d\end{array}$ & - \\
\hline Valine & $\begin{array}{l}6.02 \pm 0.02 \\
a\end{array}$ & $\begin{array}{l}5.97 \pm 0.02 \\
b\end{array}$ & $\begin{array}{l}5.33 \pm 0.01 \\
c\end{array}$ & $\begin{array}{l}5.27 \pm 0.01 \\
d\end{array}$ & $\begin{array}{l}4.52 \pm 0.02 \\
g\end{array}$ & $\begin{array}{l}4.63 \pm 0.0 \\
1^{f}\end{array}$ & $\begin{array}{l}4.80 \pm 0.01 \\
e\end{array}$ & 4.30 \\
\hline Methionine & $\begin{array}{l}1.77 \pm 0.02 \\
\mathrm{a}\end{array}$ & $\begin{array}{l}1.67 \pm 0.01 \\
b\end{array}$ & $1.55 \pm 0.01$ & $\begin{array}{l}1.62 \pm 0.01 \\
c\end{array}$ & $1.35 \pm 0.01$ & $\begin{array}{l}1.41 \pm 0.0 \\
1^{f}\end{array}$ & $e^{1.46 \pm 0.01}$ & 2.70 \\
\hline Isoleucine & $\begin{array}{l}5.91 \pm 0.03 \\
a\end{array}$ & $\begin{array}{l}5.64 \pm 0.01 \\
b\end{array}$ & $\begin{array}{l}4.76 \pm 0.01 \\
d\end{array}$ & $\begin{array}{l}4.88 \pm 0.01 \\
c\end{array}$ & $\begin{array}{l}4.19 \pm 0.01 \\
f\end{array}$ & $\begin{array}{l}4.31 \pm 0.0 \\
1^{e}\end{array}$ & $\begin{array}{l}4.31 \pm 0.01 \\
\mathrm{e}\end{array}$ & 3.20 \\
\hline Leucine & $\begin{array}{l}9.72 \pm 0.02 \\
a\end{array}$ & $\begin{array}{l}9.26 \pm 0.06 \\
b\end{array}$ & $\begin{array}{l}8.58 \pm 0.02 \\
d\end{array}$ & $\begin{array}{l}8.90 \pm 0.01 \\
c\end{array}$ & $\begin{array}{l}7.48 \pm 0.01 \\
\mathrm{~g}\end{array}$ & $\begin{array}{l}7.56 \pm 0.0 \\
3^{f}\end{array}$ & $e^{7.91 \pm 0.01}$ & 6.60 \\
\hline Threonine & $\begin{array}{l}5.72 \pm 0.01 \\
a\end{array}$ & $5.08 \pm 0.1^{c}$ & $\begin{array}{l}5.08 \pm 0.02 \\
c\end{array}$ & $\begin{array}{l}5.40 \pm 0.01 \\
b\end{array}$ & $\begin{array}{l}3.49 \pm 0.01 \\
\mathrm{~g}\end{array}$ & $\begin{array}{l}4.16 \pm 0.0 \\
1^{f}\end{array}$ & $\begin{array}{l}4.44 \pm 0.01 \\
\mathrm{e}\end{array}$ & 3.10 \\
\hline Phenylalanine & $\begin{array}{l}6.66 \pm 0.05 \\
a\end{array}$ & $\begin{array}{l}6.07 \pm 0,01 \\
b\end{array}$ & $\begin{array}{l}5.75 \pm 0.02 \\
c\end{array}$ & $\begin{array}{l}5.74 \pm 0.02 \\
c\end{array}$ & $\begin{array}{l}4.72 \pm 0.02 \\
\mathrm{~g}\end{array}$ & $\begin{array}{l}4.89 \pm 0.0 \\
1^{f}\end{array}$ & $\begin{array}{l}5.06 \pm 0.01 \\
e\end{array}$ & 5.20 \\
\hline \multicolumn{9}{|l|}{$\begin{array}{l}\text { Non-essential } \\
\text { amino acid }\end{array}$} \\
\hline Aspartic acid & $\begin{array}{l}9.87 \pm 0.01 \\
a\end{array}$ & $\begin{array}{l}9.75 \pm 0.22 \\
\mathrm{a}\end{array}$ & $\begin{array}{l}9.44 \pm 0.01 \\
b\end{array}$ & $\begin{array}{l}9.44 \pm 0.01 \\
b\end{array}$ & $\begin{array}{l}8.62 \pm 0.01 \\
d\end{array}$ & $\begin{array}{l}8.67 \pm 0.0 \\
1^{\mathrm{d}}\end{array}$ & $\begin{array}{l}8.93 \pm 0.02 \\
c\end{array}$ & \\
\hline Serine & $\begin{array}{l}4.99 \pm 0.02 \\
a\end{array}$ & $\begin{array}{l}4.95 \pm 0.01 \\
b\end{array}$ & $\begin{array}{l}4.28 \pm 0.01 \\
d\end{array}$ & $\begin{array}{l}4.47 \pm 0.01 \\
c\end{array}$ & $\begin{array}{l}3.60 \pm 0.01 \\
g\end{array}$ & $\begin{array}{l}3.85 \pm 0.0 \\
1^{f}\end{array}$ & $\begin{array}{l}3.88 \pm 0.01 \\
e\end{array}$ & \\
\hline Glutamic acid & $\begin{array}{l}12.72 \pm 0.5 \\
2^{\mathrm{a}}\end{array}$ & $\begin{array}{l}12.50 \pm 0.0 \\
2^{b}\end{array}$ & $\begin{array}{l}11.97 \pm 0.0 \\
2^{\mathrm{d}}\end{array}$ & $\begin{array}{l}12.42 \pm 0.0 \\
2^{c}\end{array}$ & $\begin{array}{l}11.32 \pm 0.0 \\
6^{9}\end{array}$ & $\begin{array}{l}11.52 \pm 0 . \\
02^{f}\end{array}$ & $\begin{array}{l}11.66 \pm 0.0 \\
1^{\mathrm{e}}\end{array}$ & \\
\hline Proline & $\begin{array}{l}4.47 \pm 0.04 \\
a\end{array}$ & $\begin{array}{l}4.03 \pm 0.03 \\
b\end{array}$ & $\begin{array}{l}3.47 \pm 0.01 \\
c\end{array}$ & $\begin{array}{l}3.36 \pm 0.02 \\
d\end{array}$ & $\underset{f}{3.05 \pm 0.03}$ & $\begin{array}{l}3.25 \pm 0.0 \\
4^{e}\end{array}$ & $\begin{array}{l}3.27 \pm 0.01 \\
\mathrm{e}\end{array}$ & \\
\hline Glycine & $\begin{array}{l}5.91 \pm 0.01 \\
a\end{array}$ & $\begin{array}{l}5.67 \pm 0.01 \\
\text { b }\end{array}$ & $\begin{array}{l}5.13 \pm 0.06 \\
d\end{array}$ & $\begin{array}{l}5.29 \pm 0.01 \\
c\end{array}$ & $\begin{array}{l}4.37 \pm 0.10 \\
f\end{array}$ & $\begin{array}{l}4.43 \pm 0.0 \\
2^{f}\end{array}$ & $\begin{array}{l}4.53 \pm 0.01 \\
\mathrm{e}\end{array}$ & \\
\hline Alanine & $\begin{array}{l}6.30 \pm 0.01 \\
a\end{array}$ & $\begin{array}{l}5.70 \pm 0.02 \\
b\end{array}$ & $\begin{array}{l}5.01 \pm 0.01 \\
d\end{array}$ & $\begin{array}{l}5.39 \pm 0.01 \\
c\end{array}$ & $\begin{array}{l}4.19 \pm 0.01 \\
f\end{array}$ & $\begin{array}{l}4.23 \pm 0.1 \\
0^{f}\end{array}$ & $\begin{array}{l}4.40 \pm 0.10 \\
\mathrm{e}\end{array}$ & \\
\hline Tyrosine & $\begin{array}{l}5.72 \pm 0.01 \\
a\end{array}$ & $\begin{array}{l}5.08 \pm 0.00 \\
c\end{array}$ & $\begin{array}{l}5.08 \pm 0.01 \\
c\end{array}$ & $\begin{array}{l}5.40 \pm 0.01 \\
b\end{array}$ & $\begin{array}{l}3.49 \pm 0.01 \\
f\end{array}$ & $\begin{array}{l}4.16 \pm 0.1 \\
5\end{array}$ & $\begin{array}{l}4.44 \pm 0.03 \\
d\end{array}$ & \\
\hline Cysteine & $\begin{array}{l}1.32 \pm 0.01 \\
\mathrm{a}\end{array}$ & $\begin{array}{l}1.06 \pm 0.01 \\
b\end{array}$ & $\begin{array}{l}0.93 \pm 0.01 \\
c\end{array}$ & $\begin{array}{l}0.93 \pm 0.01 \\
c\end{array}$ & $\underset{f}{0.66 \pm 0.02}$ & $\begin{array}{l}0.79 \pm 0.0 \\
2^{e^{-1}}\end{array}$ & $\begin{array}{l}0.86 \pm 0.02 \\
d\end{array}$ & \\
\hline
\end{tabular}

Means with the same superscript within the same row were not significantly different $(P>0.05)$

SU - raw

SW1 -Soaking in water at room temperature for 24 hours

SW2 -Soaking in water at room temperature for 48 hours

SW3 -Soaking in water at room temperature for 72 hours 
SD1 - Sundried for 24 hours

SD2 - Sundried for 48 hours

SD3 - Sundried for 72 hours

1 - WHO/FAO/UNU (2007)

Tryptophan was not detected in the amino acids profile assay . Glutamic acid was the most predominant non-essential amino acid with a range of $11.32-12.72(\mathrm{~g} / 100 \mathrm{~g}$ protein) followed by aspartic acid (8.62- $9.87 \mathrm{~g} / 100 \mathrm{~g}$ protein) while cysteine was the least abundant (0.66-1.32 $\mathrm{g} / 100 \mathrm{~g}$ protein). There was a significant $(\mathrm{P} \leq 0.05)$ reduction between the raw and all the processed leaf meal samples. Soaking led to a higher percentage reduction in all the detected amino acids when compared to the sun-drying method. The values for all the amino acids were significantly different $(P \leq 0.05)$ between the soaked and sun-dried samples. The reduction effect was observed more in some of the amino

acids (Table 1 ). A reduction of $13.87 \%$ (4.76 $5.64 \mathrm{~g} / 100 \mathrm{~g}$ protein) was observed in isoleucine and $6.59 \%(5.87-6.11 \mathrm{~g} / 100 \mathrm{~g}$ protein) in arginine for the sun-drying method (Table 1). In the soaking method, isoleucine had a reduction of $29.44 \%$ ( $4.19-4.31 \mathrm{~g} / 100 \mathrm{~g}$ protein), while lysine a reduction of $14.04 \% \quad(4.79-4.97 \mathrm{~g} / 100 \mathrm{~g}$ protein), then phenylalanine a reduction of $26.58 \%$ (4.72 $-5.06 \mathrm{~g} / 100 \mathrm{~g}$ protein).

Table 2 shows the amino acid scores of the sundried and soaked $L$. leucocephala leaf meals. Amino acid scores of the sun-dried and soaked $L$. leucocephala leaf meals when compared to the reference standard revealed that lysine $(98.6 \%)$, methionine and cysteine (95.5\%) ere the limiting amino acids for the sun-dried samples while lysine $(91.2 \%)$ methionine and cysteine $(80.7 \%)$ were the limiting amino acids for the soaked samples.

Table 2: Amino acid scores for the

raw, sun-dried and soaked $L$. leucocephala leaf meals

\begin{tabular}{|c|c|c|c|c|c|}
\hline $\begin{array}{l}\text { Essential } \\
\text { Amino acid }\end{array}$ & $\begin{array}{l}\text { Amino acids } \\
\text { concentration } \\
\text { (g/100g protein) } \\
\text { raw }\end{array}$ & $\begin{array}{l}\text { Amino acids } \\
\text { concentration } \\
\text { (g/100g protein) } \\
\text { sundried }\end{array}$ & $\begin{array}{l}\text { Amino acid } \\
\text { score }(\%)\end{array}$ & $\begin{array}{l}\text { Amino acids } \\
\text { concentration } \\
\text { (g/100g protein) } \\
\text { soaked }\end{array}$ & $\begin{array}{l}\text { Amino acid } \\
\text { score (\%) }\end{array}$ \\
\hline Lysine & 6.05 & 5.62 & 98.5 & 5.2 & 91.2 \\
\hline Histidine & 2.97 & 2.57 & 128.5 & 2.27 & 113.5 \\
\hline Valine & 6.02 & 5.52 & 128.3 & 4.65 & 108.1 \\
\hline $\begin{array}{l}\text { Methionine } \\
\text { and Cysteine }\end{array}$ & 3.07 & 2.58 & 95.5 & 2.18 & 80.7 \\
\hline Isoleucine & 5.91 & 5.09 & 184.3 & 4.17 & 130.3 \\
\hline Leucine & 9.72 & 8.91 & 135 & 7.65 & 116 \\
\hline Threonine & 5.72 & 5.19 & 167.4 & 4.03 & 130 \\
\hline $\begin{array}{l}\text { Phenylalanine } \\
\text { and Tyrosine }\end{array}$ & 12.38 & 11.03 & 212.1 & 8.92 & 171.5 \\
\hline
\end{tabular}

The concentrations of the various amino acids detected in the raw, sun-dried and soaked $L$. leucocephala leaf meals are presented in Table 3 with the aim of providing data on protein quality. The concentration of the total essential amino acids (TEAA) of the raw L. leucocephala leaf meal was $51.19 \mathrm{~g} / 100 \mathrm{~g}$ protein which was higher than that of the sun-dried (46.00-48.04 g / $/ 100 \mathrm{~g}$ protein) and soaked (38.00-41.79 g / $/ 100 \mathrm{~g}$ protein) samples. The levels of total non-essential amino acids (TNEAA) for the $L$. leucocephala leaf meal samples followed the same pattern : sun- 
dried (46.70-48.81 g $/ 100 \mathrm{~g}$ protein) and soaked (39.3-41.97 g /100g protein) which were lower than the raw $(50.61 \mathrm{~g} / 100 \mathrm{~g}$ protein) sample. The total non-essential amino acids (TNEAA) were generally higher in concentration compared to the total essential amino acids (TEAA) for the processed samples.

Table 3: Concentrations of the amino acids from the meals

\begin{tabular}{llllllll}
\hline $\begin{array}{l}\text { Amino acid } \\
(\mathrm{g} / 100 \mathrm{~g} \text { protein) }\end{array}$ & \multicolumn{9}{c}{ Treatments } \\
& SU & SD1 & SD2 & SD3 & SW1 & SW2 & SW3 \\
\hline TEAA (Total Essential Amino Acids) & 51.19 & 48.04 & 44.91 & 46.00 & 38.00 & 39.55 & 41.79 \\
TNEAA (Total Non-Essential Amino Acids) & 50.61 & 48.81 & 45.31 & 46.7 & 39.3 & 40.9 & 41.97 \\
TSAA (Total sulfur-containing amino & 3.09 & 2.73 & 2.48 & 2.55 & 2.01 & 2.20 & 2.32 \\
acids) & & & & & & & \\
\hline
\end{tabular}

SU - raw

SW1 -Soaking in water at room temperature for 24 hours

SW2 -Soaking in water at room temperature for 48 hours

SW3 -Soaking in water at room temperature for 72 hours

SD1 - Sundried for 24 hours

SD2 - Sundried for 48 hours

SD3 - Sundried for 72 hours

\section{Discussion}

This study corroborated the work of Chinyere and Obasi (2011) on the predominance of leucine as the most abundant essential amino acid in selected vegetables. Igwe et al. (2012) and Oluwasola and Dairo (2016) gave similar results for legumes and Tithonia diversifolia leaves, respectively. Methionine being the most abundant essential amino acid is in line with the work of Mirinda et al. (2012) on fresh $L$. leucocephala leaves and Okereke and Ucheje (2014) working on leaf, root and seed of Moringa oleifera. Chinyere and Obasi (2011) stated that legume leaf vegetables are low in sulphurcontaining amino acids (methionine and cysteine). The absence of tryptophan might be a result of acid hydrolysis employed in the determination of amino acid composition, tryptophan requires alkaline hydrolysis (Nwosu et al., 2008). The result also reveals that processing by soaking in water led to a significant reduction $(P \leq 0.05)$ in all the essential amino acids considered in this study.

Madalla et al. (2013) reported a high reduction in value of sulphur- containing amino acids (methionine and cysteine) when Moringa leaves were soaked in water overnight. The lower amino acids content of the soaked Leucaena leaf meal when compared with the sun-dried one may be attributed to loss of soluble nitrogenous compounds and free water-soluble amino acids through leaching. This study supports the observation of Augustine et al. (2018) that there was a decrease in amino acids composition of Senna occidentalis as soaking time increased. The essential amino acid composition of the processed Leucaena leaf meals in this study was similar to those reported by earlier workers (Hetrampf and Piedad-pascual, 2003; Minrida et al., 2012). The findings of this experiment revealed that most of the essential amino acids in all the processing methods scored above $100 \%$ of the WHO/FAO/UNU standard for preschool age children. This shows that the processed Leuceana leaf meals are a rich source of essential amino acids. The limiting amino acid being lysine and sulpur-containing amino acids has also been reported by Chinyere and Obasi (2011) for some Nigerian vegetables (Veronica amygdaline, Gnetum africana, Gongronema latifolium and Ocimum gratissimum). The higher level of TNEAA (Total Non-Essential Amino Acids) when compared to TEAA (Total Essential Amino Acids) followed the pattern reported by Igwe et al. (2012) for processed seeds of Prosopis africana and Ricinus communis. However, the values for TNEAA (Total Non-Essential Amino Acids) and TEAA (Total Essential Amino Acids) were close to 
the value reported by Minrida et al. (2012) for Leucaena leaf.

\section{Conclusion}

Soaking and sun-drying processing methods caused different degrees of significant reduction in all amino acids evaluated in this study. However, L. leucocephala leaf contains appreciable quantities of essential and nonessential amino acids comparable with some animal proteins and other common legumes. This study indicated sun-drying followed by soaking as being desirable in reducing amino acid losses. The amino acids scores also revealed that lysine, methionine and cysteine were the limiting amino acids in the processed Leucaena leaf meals when compared with WHO/FAO/UNU standard for preschool age children. Therefore, processed Leucaena should be supplemented with other feed ingredients rich in these amino acids for fish nutrition.

\section{References}

Adedeji, O.S., Amao, S.R., Ameen, S.A., Adedeji, T.A. and Ayandiran, T.A. (2013). Effects of varying levels of Leucaena leucocephala leaf meal diet on the growth performance of weaner rabbit. Journal of Env. Issues and Agric. Dev. Countries. 5(1): 5-9.

Amisah, S., Oteng, M.A. and Ofori, J.K. (2009). Growth performance of the african catfish, Clarias gariepinus fed inclusion levels of Leucaena leucocephala leaf meal. Journal of App. Sci. and Env. Man. 13 (1): 23-26.

A.O.A.C. (1990).Official Methods of Analysis. Association of Official Analytical Chemistry vol.13 Washington, USA pp. 1234.

Augustine, C., Igwebuike, J.U., Midau, A., Tarimbuka, L.I., Salomsi, A.A., Abdulraheem, O.A., Medugu, C.I. and Abdulrahman, B.S. (2018). Impact of soaking periods on the chemical composition of coffee senna ( Senna occidentalis linn ) leaves. Inter. J. of Recent Inno. Aca. Res. 2(2):2635-3040

Aye, P.A and Adegun M. K. (2013). Chemical composition and some functional properties of Moringa, Leucaena and Gliricidia leaf meal. American J. of Food and Nut. (1):71-77.
Ayssiwede, S.B., Zanmenou, J.C., Issa, Y., Hane, M.B., Dieng. A., Chrysostome., A.M., Houinato, M.R., Hornick, J.L. and Missohou, L. (2011). Nutrient composition of some unconventional and local feed resources available in Senegal and recoverable in indigenous chicken or animal feeding. Pakistan J. of Nut. 10(8): 707711.

Benitez, L.V. (1989). Amino acid and fatty acid profiles in aquaculture nutrition. De Silva, S. (Ed), Fish Nutrition Research in Asia, Proceedings of the Third Asian fish nutrition network meeting. Asian fisheries society special publication, 4(166):23-25. Asian fish. Soc. Manila Phillipines.

Chinyere, G.C and Obasi, N. A. (2011). Changes in the amino acids contents of selected leafy vegetable subjected to different processing treatments. African J. of Biochem. Res. 5(6):182 $-187$.

Dalibard, P., Hess, V., Le Tutour, L., Peisker, M., Peris, S., Perojo Gutierrez, A. and Redshaw, M. (2014). Amino acids in animal nutrition. Fefena Publication 92pp

Faroughbakhch, R., Hemandez-pinero, L., Raminrez, N. and Alvarado, A. (2007). Nutrients, minerals, volatile fatty acids content in four Leucaena Species and the hybrid k743. Journal of Ani. and Vet. Adv. 6(9): 1083-1087.

Francis, G., Makkar, P.S. and Becker, K. (2001). Antinutritional factors present in plant derived alternate fishfeed ingredients and their effects in fish. Aqua. 199:197-227.

Hertrampf, W.J. and Piedda-Pascual, F. (2003). Handbook on ingredients for aquaculture feed. Kluwer Academic Publishers, pp.624.

Heuzer, V., and Tran .G. (2014). Leucaena leucocephala. Feedpedia.org. A programme by INRA, CIRAD, AFZ and FAO. http://www.feedi.pedia.org/node/282 Retrieved 23/6/14.

Igwe, C.U., Ojiako, O.A., Anugweje, K.C., Nwaogu, L.A. and Ujowundu, C. O. (2012). Amino acid profile of raw and locally processed seeds of Prosopis africana and Ricinus communis: potential antidotes to protein 
malnutrition. Func. Foods in Health and Dis.

2(4):107-119.

Madalla, N., Agbo, W. and Jauncey, K. (2013). Evaluation of aqueous extracted Moringa leaf meal as a protein source for Nile Tilapia juveniles. Tanzania J. of Agric. Sci. 12(1): 53-64.

Mirinda, L.F., Rodriguez, N. M., Periera, E.S., Queiroz, A.C., Sarinz, R.D., Pimentel, P.G. and Gonlizo, M.M. (2012). Chemical composition and rumen degradation, kinetics of crude protein, amino acids and intestinal digeslibility of amino acid from tropical forages. Rev. Brasileira de Zoo. 41(3) $717-725$.

Monoj, K.G. and Bandyopadhyay, S. (2007). Mimosine toxicity-A problem of Leucaena feeding in ruminants. Asian J. of Ani. and Vet. Adv. 2(2):63-73.

Nwosu, J.N., Ubbaonu, C.N., Banigo, E.O.I. and Uzomah, A. (2008). The effects of processing on the amino acid profile of 'Oze' (Bosqueia angolensis) seed flour. Life Sci. Journal 5(4): 69 74.

Okereke, C. J and Ucheje, O. (2014). Effect of processing on the amino acid profile of the leaf, root and seed of Moringa oleifera grown in Rivers State, Nigeria. Ann. of Bio. Res. 5 (8):8-12

Oluwasola, T. A. and Dairo, F. A. (2016). Proximate composition, amino acid profile and some anti-nutrients of Tithonia diversifolia cut at two different times. African J. of Agric. Res. 11(38):3659-3663.

Onimisi, H. U., Oniye, S. J. and Bolorunduro, P. I. (2017). Nutritional evaluation of boiled Senna obtusifolia (linn) seed meal for fish nutrition. Journal of Ani. Pro. Res. 29(1): 312-320

Robinson, E.H. and Menghe, H.L. (2007). Catfish protein nutrition (Revised). Bulletin 1153, Office of Agricultural Communications. Mississipi State University, USA.22pp.

WHO/FAO/UNU (2007). Protein and Amino Acid Requirements in Human Nutrition; Report of a joint WHO/FAO/UNU Expert Consultation, WHO Tech Rep Ser No 93 Geneva 